\title{
Habitat Description of the Threatened Freshwater Clam, Galatea paradoxa (Born 1778) at the Volta Estuary, Ghana
}

\author{
K.A. OBIRIKORANG, S. AMISAH and D. ADJEI-BOATENG
}

\begin{abstract}
Department of Fisheries and Watershed Management, Faculty of Renewable Natural Resources,
\end{abstract} Kwame Nkrumah University of Science and Technology (KNUST), Kumasi, Ghana.

http://dx.doi.org/10.12944/CWE.8.3.01

(Received: August 20, 2013; Accepted: October 05, 2013)

\begin{abstract}
This research was conducted to at two of the few remaining habitats of the threatened freshwater clam (Galatea paradoxa) at the Volta Estuary in Ghana to describe the current state of the clam habitat with respect to the physicochemical water parameters and the characterize the bottom sediment on which they thrive. The research was carried out over an 18-month period with the aim of facilitating the transplanting of juvenile clams from their natural habitats to portions of the estuarine environments with similar physicochemical and characteristics which will consequently lead to the conservation of the clampopulation and expansion of the clam habitat. The measured physicochemical water parameters were fairly similar at the two locations and exhibited temporal fluctuations which could be attributed to seasonal changes as well as anthropogenic activities within the catchment of the sampling locations. The results of the grain size analyses revealed very low sedimentological diversity and it was observed that the estuarine sediments fall under the sandy textural group (>95\%) which characterized both sampling locations in the Estuary.
\end{abstract}

Key words: Galatea Paradoxa, Conservation, Volta Estuary, Ghana.

\section{INTRODUCTION}

The freshwater clam, Galatea paradoxa (Born 1778) is a bivalve mollusc belonging to the family Donacidae (Purchon, 1963) and is usually restricted to the lower reaches of a few rivers in West Africa including the Volta inGhana (King and Udoidiong, 1991).It constitutes an important and affordable protein source to the riparian human communities of the Lower Volta, and has for centuries been the basis of a thriving artisanal fishery and a means of livelihood for between 10002000 people(Amador, 1997). The sale of harvested clams from the fishery is worth between $4.8-9.6$ million Ghana Cedis (US\$3.31- 6.72 million) annually (Adjei-Boateng et al., 2012). Additionally, the shell of the clam has a number of important uses notably as source of calcium in animal feed, especially poultry feed, and in the manufacture of local paints. The shells are also used as an alternative to stone chippings in concrete and as pavement material such as terrazzo floors and to overcome muddy conditions in village compounds in the southern parts of the Volta Region, Ghana.

Unfortunately, the pervasive paucity of empirical data for species management and habitat loss through over-exploitation and the damming of the River have significantly reduced the population size of this species that was once abundant within this zone. The construction of the Akosombo and Kpong Hydroelectric Dams on the Volta River in 1964 and 1981 respectively have led to the subsequent absence of annual floods and the formations of sandbars which have gradually prevented the flow of saline water upstream into the River channel during high tides (UNEP, 2002). The changes in the flow regime have led to physicochemical changes in the water and consequently, there has been a gradual but massive shift in the habitat of Galatea paradoxa from the upper and mid-section of the lower Volta River 
towards the Estuary with a substantial decline in abundance of the clam. The distribution of Galatea paradoxa is currently restricted to a very narrow stretch of the south Volta River, between AgaveAfedume (15 km from the Volta Estuary) and AdaFoah (10 km from the Estuary) (Amador, 1997), just a small fraction compared to the pre-dam period when the clam industry stretched as far as between Sogakope and Akuse (between 20 and $95 \mathrm{~km}$ from the Volta Estuary) (Lawson, 1963).Landings from the clam fishery have also drastically dwindled from 8000 tonnes a year (Lawson, 1963), prior to the construction of the Akosombo dam, to 1700 tonnes (Amador, 1997). As a result of the habitat alteration and over-exploitation of the clam resource, commercial extinction of the clam is imminent in Ghana with immense socio-economic consequences for villagers, especially women whose livelihoods depend on the fishery. Presently, there is the practice of culturing juvenile clams in the lower Volta River which involves transplanting the clams from their natural population in the Volta Estuary to individual or family-owned sites up-river for on-growing during the dry season. This practice ensures the provision of clams for domestic consumption and for sale during the clam fishing close season which spans the entirety of the dry season, from December to March each year (Prein andOfori, 1996, Brown 2006).The clam culture is, however, practiced on a very small scale by a few families and individuals although steps can be taken to ensure the intensification of this practice which will ultimately lead to an increase in the extent of the clam habitat and population.

This research was therefore conducted to contribute to the description of the current clam habitat with respect to the physicochemical water parameters and bottom sediment characteristics to facilitate the transplanting of juvenile clams to portions of the estuarine environments with similar characteristics and consequently lead to the conservation of the Galatea paradoxapopulation and expansion of the clam habitat. This research will also provide vital baseline data of the essential for the management and conservation of the Estuary's clam population and serve as a basis for measuring future changes in the bottom sediment characteristics and physicochemical water parameters of the Estuary.

\section{MATERIALS AND METHODS}

\section{Study Area}

The study was carried out at two locations, Ada and Aveglo, both at the Volta Estuary, Ghana, over an 18-month period, from March 2008 to August 2009. Ada (Latitude $05^{\circ} 49^{\prime} 18.6^{\prime \prime} \mathrm{N}$ and $\left.000^{\circ} 38.46^{\prime} 11^{\prime \prime E}\right)$ and Aveglo (05 53 28.2" $\mathrm{N}$ and $\left.000^{\circ} 38^{\prime} 24.7 " \mathrm{E}\right)$ respectively represent the southern and northern limits of the most active clam fishing grounds at the Volta Estuary (Figure 1). This study spanned over the major and minor rainy seasons as well as the dry season (the Harmattan) to give a detailed description of the physicochemical parameters and bottom sediment character of the Estuary and capture the seasonal fluctuations and trends.

\section{Climatology and Geology of the Study Area}

The climate of the study area lies within the dry Equatorial climatic region of Ghana, which also covers the entire coastal belt of the country. This region is the driest in the country and is referred to as the central and south-eastern coastal plains. The coastal lands of Ghana have two clearly defined seasons, the Dry season and the Rainy season. The Rainy season exhibits double maxima, the main one occurring between April and June and the minor one between September and October. June is normally the wettest month in the area.The southern part of the main Volta Basin, including the two study sites at the Estuary consists of mainly metamorphic rocks, including hornblende and biotite, gneisses, migmatites, granulites, and schist (UNEP, 2002). The relief of the riverbed leading to the Estuary as well as that of the surrounding areas of the Estuary is smooth with a very low gradient. Water depths, even at large distances from the coast are shallow and the flow of the Lower Volta River (105km long) is presently almost completely regulated by the Akosombo Dam with an average flow of $1150 \mathrm{~m} / \mathrm{s}$. Further modifications have been imposed by the Kpong Dam, situated25km downstream of the Akosombo Dam. This new flow regime between Kpong $(95 \mathrm{~km}$ from the Estuary) and the Estuary has resulted in a progressive growth of sandbars at the Estuary, which restricts flood discharge (into the sea) and tidal movement into the River(Pople and Rogoyska, 1969). 
Collection and Processing of Sediment Samples for Granulometric Analysis

Surface sediment samples $(0-5 \mathrm{~cm})$ were collected on a monthly interval for 18 months using annon-contaminating stainless steel Ekman grab (Duncan and Associates, Cumbria, UK) deployed from a boat at the two locations from March 2008 to August 2009. Twenty (20) samples were collected from random and adequately-spaced out points at each sampling site according to the standard procedures described in USEPA's sediment sampling guide (USEPA, 1994) and stored separately in $500 \mathrm{ml}$ pre-washed LDPE bottles.

In the laboratory the sediment samples from each sampling point of the two locations were placed in separate ceramic mortars for drying at $80^{\circ} \mathrm{C}$ for $48 \mathrm{hrs}$ to a constant weight in a hot air oven (Phillips and Yim, 1981). All visible aquatic organisms and shell fragments, grass, leaves and roots when present were manually removed from the sediment samples prior to oven drying. The dried samples were disaggregated using an agate mortar and pestle. The disaggregation was gently done in order to retain, as much as possible, the intrinsic grain sizes of the samples. $250 \mathrm{~g}$ of each sample was subsequently storedfor the granulometric analyses which broadly adhered to the USEPA(1994) protocols.

\section{Granulometric Analysis of Sediments}

The granulometric analysis of the surface sediments from the two sampling sites was carried out following the procedures described in Cardoso et al., (2008). Grain size analysis was performed based on a series of sieves of different mesh sizes. The sieves were arranged such that the screen with the smallest mesh size was at the base and the largest at the top. A pan was placed below the series of sieves to collect the very fine particles. Sediment description was based on the following fractions; clay $(<0.002 \mathrm{~mm})$, silt $(0.002-0.02 \mathrm{~mm})$ and sand (0.02-2mm). The sand component was further broken down into further fractions; very fine sand $(0.02-0.06 \mathrm{~mm})$, fine sand $(0.06-0.2 \mathrm{~mm})$, medium sand $(0.2-0.6 \mathrm{~mm})$, and coarse sand $(0.6-2 \mathrm{~mm})$. The

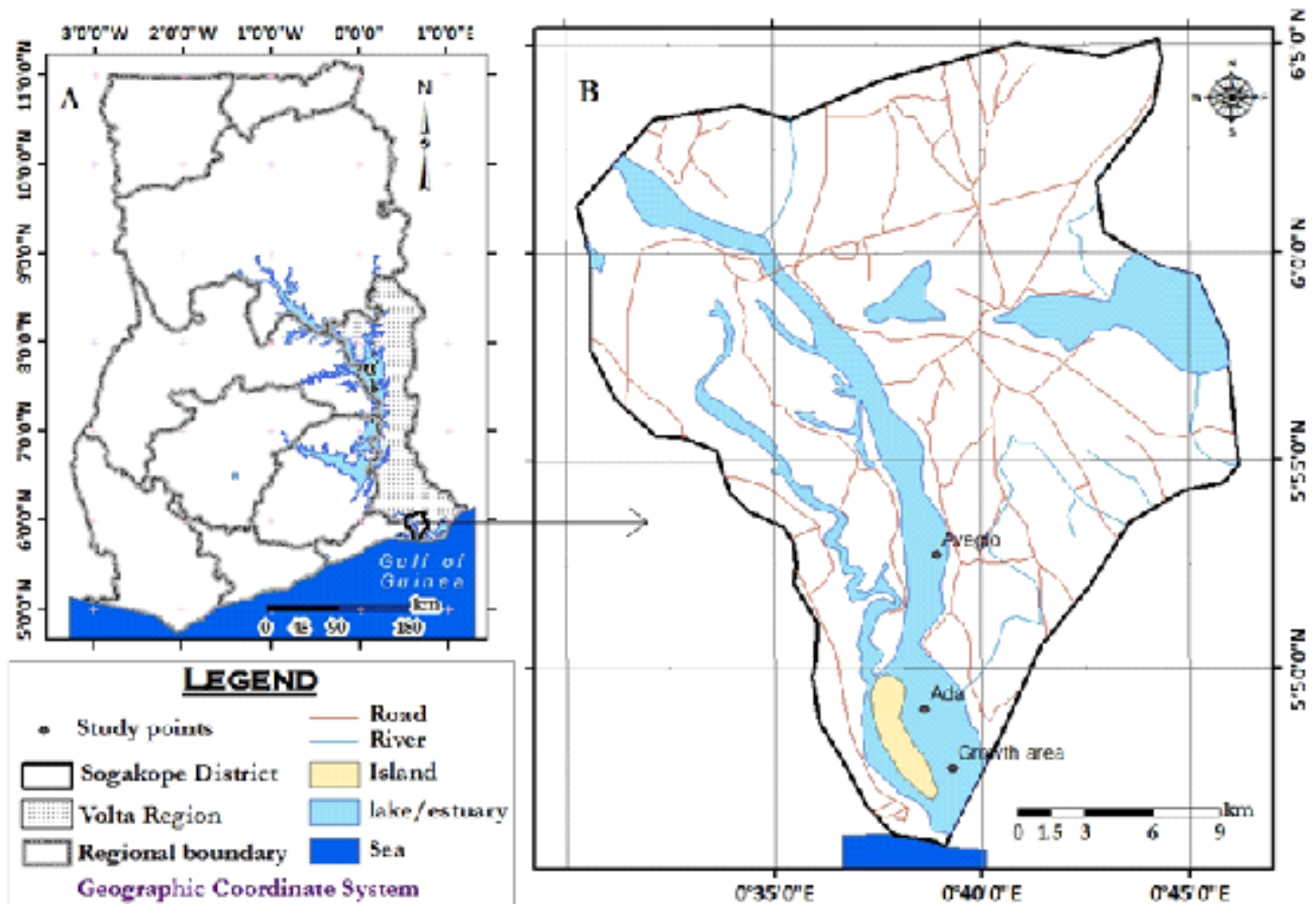

Fig. 1: Map showing the sampling locations at Ada and Aveglo in the Volta Estuary in Ghana 

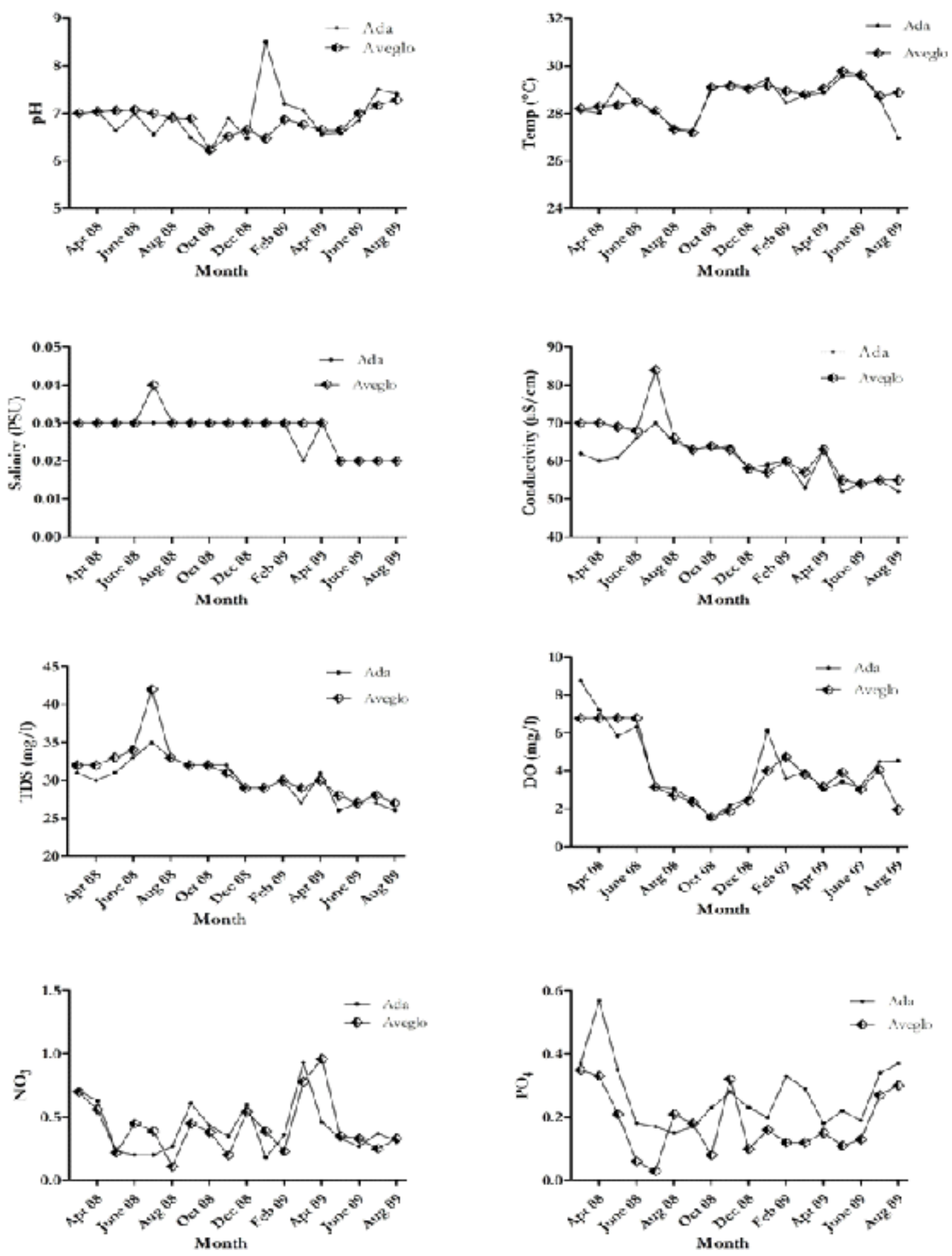

Fig. 2 :Trends in physicochemical water parameters of the Volta Estuary from March 2008 to August 2009 
fraction retained in each sieve and the pan was weighed and expressed as a percentage of the total sediment weight.

\section{Physicochemical Water Parameters}

Monthly measurement of temperature, salinity, $\mathrm{pH}$, pressure, total dissolved solids (TDS), conductivity and dissolved oxygen (DO) of the Volta Estuary were taken in-situ at both sites for the period using a Hanna HI 9028 multi-parameter probe (Hanna Instruments, Woonsocket, Rhode Island, USA) during high and low tides. Water samples were also collected each month at each sediment sampling point atthe two stations in a clean, 1-litre LDPE sample bottles, stored on ice at approximately $4^{\circ} \mathrm{C}$ and subsequently analyzed in the laboratory within 12 hours for Nitrates and Phosphates using a Wagtech Photometer 7100 (Wagtech WTD, Tyne and Wear, UK).

\section{Statistical Analysis}

The Mann-Whitney non-parametric test was used to test for differences $(p<0.05)$ in the measured physicochemical at the two sampling stations over the 18-month period.All descriptive statistics and graphs were executed using the GraphPad Prism 5 Software (Graphpad Software Inc, California, USA).

\section{RESULTS AND DISCUSSION}

\section{Physicochemical Parameters of the Volta Estuary}

The $\mathrm{pH}$ of the water did not show any clear trends at both sampling stations over the sampling period. This lack of pattern is probably due to the fact that wind induced mixing could lead to a very homogeneous water mass and the fairly high carbonate content of the water would have effectively buffered any $\mathrm{pH}$ changes that could have resulted from biotic activity (Finlayson, 2000).pH for the Ada sampling station ranged between 6.18 in October 2008 and 8.50 in January 2009 and values were fairly constant from March to December 2008. At the Aveglo sampling station, $\mathrm{pH}$ values were similar to the values recorded at Ada over the sampling period although values were generally slightly lower during most of the sampling period. The $\mathrm{pH}$ values ranged between 6.23 in October 2008 to 7.28 in August 2009.
Temperature values over the 18-month period varied between a narrow range of $27.28^{\circ} \mathrm{C}$ and $29.59^{\circ} \mathrm{C}$ in September 2008 and June 2009 for the Ada sampling station and between $27.19^{\circ} \mathrm{C}$ and $29.62^{\circ} \mathrm{C}$ for the Aveglo sampling station. These values fell within the long-term-temperature range values from the Ada Synoptic Station which indicated that the minimum average temperature is $24^{\circ} \mathrm{C}$, whereas the maximum average is $31^{\circ} \mathrm{C}$.Dissolved oxygen (DO) values for the Ada sampling station ranged from a low of $1.52 \mathrm{mg} / \mathrm{l}$ in September 2008 to $8.76 \mathrm{mg} / \mathrm{l}$ in March 2008. The values dropped steadily from March to October 2008 after which there was a progressive increase to the end of the sampling period, although there were periodic drops during certain months. DO values at the Aveglo sampling station exhibited a trend similar to that of the Ada sampling station with values dropping steadily from March to October 2008 indicating a similar underlying factor responsible for the decline. DO values of the Aveglo portion of the Estuary ranged between 1.58 and $6.78 \mathrm{mg} / \mathrm{l}$. DO levels at both stations were reasonably high and fairly constant throughout but appeared to decline for both locations in July August and September 2008. The periods of low DO concentrations coincided with the peak of the rainy season, during which the estuary possibly might have received polluted run-off from the various metal fabrication factories, waste disposal sites and farming locations along the basin which could well have impacted negatively on the DO levels. Although the decline in oxygen levels can be attributed to anthropogenic factors, the amount of oxygen available for aquatic life also depends on a number of factors that affect the solubility of oxygen in water. These factors include salinity, temperature, atmospheric exchange, barometric pressure, currents, upwelling, tides and certain biological processes (Davis 1975).

Salinity at the Ada sampling station was constant at 0.03 PSU throughout the periods of March 2008 to February 2009. Salinity values dropped to 0.02 PSU in March, 2009 and remained constant to August 2009 although April 2009 recorded a salinity value of 0.03 PSU. At Aveglo, salinity was similarly fairly constant at 0.03 for all the months from March to September 2008 except July of that same year, which recorded a slightly 
higher value of 0.04 . There was a drop in salinity from 0.03 to 0.02 PSU from April to August, 2009.

The sudden drop in $\mathrm{pH}$ at the two stations could be attributed to the dredging of the Volta Estuary, initiated and carried out in April 2009 by the Volta River Authority (VRA) which aimed at breaking down sandbars created by heaps of sand at the Estuary. The dredging process may have caused the re-suspension of anoxic sediments leading to their oxidation, which results in the formation of sulphuric acid causing a lowering of the $\mathrm{pH}$ (Peltola and Astrom 2002).

Levels of total dissolved solids (TDS) were fairly constant at Ada with values ranging between
31 and $35 \mathrm{mg} / \mathrm{l}$ over the sampling period. TDS values at the Aveglo sampling station ranged from a low $27 \mathrm{mg} / \mathrm{l}$ to a high of $42 \mathrm{mg} / \mathrm{l}$ during the sampling period. Conductivity values similarly ranged from $52 \mu \mathrm{s} / \mathrm{cm}$ in May and August 2009 to $70 \mu \mathrm{s} / \mathrm{cm}$ in July 2008 for the Ada sampling station and from 54 and $84 \mu \mathrm{s} / \mathrm{cm}$ at Aveglo during the sampling period.

At the Ada sampling station, the mean nitrate value over the sampling period was $0.15 \pm$ 0.087 . Higher levels of nitrate recorded in March 2008 (0.71 mg/l) and March 2009 (0.93) might have been because of surface run-off from farms and animal pens as well as well as from surrounding refuse dumps as the two periods coincided with the onset of the major rainy season in Ghana. The

Table 1: Physico chemical Parameters of the Volta Estuary at Ada and Aveglo

\begin{tabular}{llll}
\hline Sampling Station & Parameter & \multicolumn{2}{c}{ RangeMean \pm SD } \\
\hline \multirow{2}{*}{ Ada } & pH & $6.18-8.50$ & $6.94 \pm 0.52$ \\
& Temperature $\left({ }^{\circ} \mathrm{C}\right)$ & $27.28-29.59$ & $28.60 \pm 0.80$ \\
& Salinity $(\mathrm{PSU})$ & $0.02-0.03$ & $0.027 \pm 0.005$ \\
& DO $(\mathrm{mg} / \mathrm{l})$ & $1.52-8.76$ & $4.19 \pm 1.93$ \\
& $\mathrm{TDS}(\mathrm{mg} / \mathrm{l})$ & $27-35$ & $30.06 \pm 2.65$ \\
& Conductivity $(\mu \mathrm{S} / \mathrm{cm})$ & $52-70$ & $60 \pm 5.16$ \\
& Total Alkalinity $(\mathrm{mg} / \mathrm{l})$ & $30-70$ & $44.38 \pm 9.70$ \\
& Nitrate $(\mathrm{mg} / \mathrm{l})$ & $0.18-0.93$ & $0.44 \pm 0.23$ \\
& Phosphate $(\mathrm{mg} / \mathrm{l})$ & $0.15-0.57$ & $0.27 \pm 0.11$ \\
Aveglo & pH & $6.23-7.28$ & $6.85 \pm 0.27$ \\
& Temperature $\left({ }^{\circ} \mathrm{C}\right)$ & $27.19-29.62$ & $28.68 \pm 0.69$ \\
& Salinity $(\mathrm{PSU})$ & $1.02-0.04$ & $0.028 \pm 0.005$ \\
& DO $(\mathrm{mg} / \mathrm{l})$ & $27-4.79$ & $3.89 \pm 1.80$ \\
& TDS $(\mathrm{mg} / \mathrm{l})$ & $54-84$ & $31 \pm 3.48$ \\
& Conductivity $(\mu \mathrm{S} / \mathrm{cm})$ & $30-70$ & $62.83 \pm 7.62$ \\
& Total Alkalinity $(\mathrm{mg} / \mathrm{l})$ & $0.14-0.96$ & $44.16 \pm 9.63$ \\
& Nitrate $(\mathrm{mg} / \mathrm{l})$ & $0.03-0.35$ & $0.44 \pm 0.23$ \\
& Phosphate $(\mathrm{mg} / \mathrm{l})$ & $0.18 \pm 0.098$ \\
\hline
\end{tabular}

Table 2: Composition of the Bottom Sediment of the Two Sampling Stations

\begin{tabular}{llll}
\hline Sampling Station & Composition & Range (\%) & Mean \pm SD (\%) \\
\hline Ada & Clay $(<0.002 \mathrm{~mm})$ & $0.32-1.58$ & $0.85 \pm 0.36$ \\
& Silt $(0.002-0.02 \mathrm{~mm})$ & $0.04-1.57$ & $0.54 \pm 0.56$ \\
\multirow{3}{*}{ Aveglo } & Sand $(0.02-2 \mathrm{~mm})$ & $97.26-99.34$ & $98.56 \pm 0.68$ \\
& Clay $(<0.002 \mathrm{~mm})$ & $0.14-2.32$ & $0.95 \pm 0.75$ \\
& Silt $(0.002-0.02 \mathrm{~mm})$ & $0.04-2.46$ & $0.85 \pm 0.76$ \\
& Sand $(0.02-2 \mathrm{~mm})$ & $96.14-99.48$ & $98.20 \pm 1.32$ \\
\hline
\end{tabular}


major anthropogenic source of Nitrate might probably have come from N-P-K fertilizers applied to surrounding farmlands. Similar trends were observed at the Aveglo sampling station which recorded maximum and minimum Nitrate values of $0.70 \mathrm{mg} / \mathrm{l}$ and $0.96 \mathrm{mg} / \mathrm{l}$ in March, 2008 and March 2009 respectively.

Phosphate levels in the Estuary ranged between 0.03 and $0.57 \mathrm{mg} / \mathrm{l}$ during the period. Phosphate levels were higher at Ada than at Aveglo for almost all the months probably because of the proximity of that section of the Estuary to more human settlements and developments. The elevated levels of phosphate in the Estuary could come from sources such as wastewater effluents, detergents, fertilizers (NPK), soil run-off, and synthetic materials which contain organophosphates, such as insecticides and pesticides. The mean values as well as ranges of the measured physicochemical parameters are shown in Table 1.

\section{Spatial Variations and Temporal Trends in the Physicochemical Parameters}

With the exception of phosphate levels, no significant differences $(p>0.05)$ were observed between the two stations as far as the levels of the studied physicochemical parameters were concerned. Phosphate levels were generally higher at the Ada sampling station probably due to anthropogenic effects. Ada, which is geographically closer to the Estuary, has over the past few years, experienced rapid demographic changes and population growth, and the establishment of more human settlements. The resulting domestic effluent discharges and surface run-off from the cultivated fields and other land-based sources might have increased the phosphate levels of the estuarine waters at Ada.The temporal trends in the physicochemical parameters for both sampling stations over the 18-month sampling period are shown in and Fig. 2.

\section{Granulometric Analysis of the Sediment Samples}

The results of the grain size analyses revealed very low sedimentological diversity and it was observed thatthe estuarine sediments fall under the sandy textural group. This sandy substratum characterized both sampling locations in the Estuary. The granulometric analyses for the Ada sediments revealed the following composition: sand (between $97.26 \%$ and $99.34 \%$ ). Mean silt and clay composition jointly constituted less than $3 \%$ of the sampled sediment - silt ranged between 0.04 and $1.57 \%$ and clay, between 0.32 and $1.58 \%$ (Table 2). At the Aveglo station the results of the granulometric analysis was similar to the trend observed for the Ada sediments. The sand component was very dominant in all the subsamples and ranged between 96.14 and $99.48 \%$. The clay and silt components of the sampled sediments ranged between $0.14-2.32 \%$ and $0.04-2.46 \%$.

Further analyses of the sand component of the sediment revealed that it was predominantly coarse sand (between $63.36 \%$ and $98.71 \%$ ) (Table 3).

\section{CONCLUSION}

This research is a first approach in the efforts aimed at conserving and expanding the

Table 3: Particle Size Distribution of the Sand Component of the Estuarine Sediments

\begin{tabular}{llll}
\hline Sampling Station & Particle Size Distribution & Range (\%) & Mean \pm SD (\%) \\
\hline Ada & Very Fine Sand $(0.02-0.06 \mathrm{~mm})$ & $0.10-0.22$ & $0.93 \pm 0.62$ \\
& Fine Sand (0.06-0.2mm) & $0.14-6.0$ & $2.35 \pm 1.67$ \\
& Medium Sand (0.2-0.6mm) & $0.31-27.76$ & $17.76 \pm 7.25$ \\
\multirow{2}{*}{ Aveglo } & Coarse Sand (0.6-2mm) & $64.34-98.11$ & $77.34 \pm 8.21$ \\
& Very Fine Sand (0.02-0.06mm) & $0.06-1.76$ & $0.57 \pm 0.47$ \\
& Fine Sand (0.06-0.2mm) & $0.18-7.84$ & $2.95 \pm 2.92$ \\
& Medium Sand (0.2-0.6mm) & $0.31-30.76$ & $14.19 \pm 9.82$ \\
& Coarse Sand (0.6-2mm) & $64.34-98.11$ & $80.53 \pm 12.21$ \\
\hline
\end{tabular}


present clam habitat at the Volta Estuary through culture, to alleviate the fishing pressure on the remaining clam population. The results of this research can serve as reference data for stakeholder institutions like the Fisheries Commision, the District Assemblies and local authorities in their efforts to zone out potential clam culture sites and empower individuals and groups to engage in clam culture at the Lower Volta River.The development of clam culture will enhance economic activities in the lower Volta and improve the livelihoods of villagers and the general wellbeing of the communities.

\section{ACKNOWLEDGEMENT}

The authors are grateful to the International Foundation for Science (IFS) for providing financial support $(\mathrm{A} / 4421-1)$ to conduct this research work and the Department of Fisheries and Watershed Management of the Kwame Nkrumah University of Science and Technology, Kumasi for logistical support.

\section{REFERENCES}

1. Adjei-Boateng, D., Agbo, N.W., Agbeko, N.A., Obirikorang, K.A and Amisah, S. The current state of the Volta clam, Galatea paradoxa(Born 1778) fishery. Proceedings of the 16th Biennial Conference of the International Institute of Fisheries Economics and Trade (IIFET), Tanzania (2012).

2. Amador, M.K. A review of the Volta clam, Egeriaradiatafishery in the Lower Volta. BSc. Thesis submitted to the Dept. of Fisheries and Watershed Mgt, KNUST, Kumasi, Ghana (1997).

3. Brown, J. H. Shellfish culture in West Africa; economic and sustainable opportunities for artisanal fishing communities. Background paper for FAO/DFID SFLP Policy brief series, FAO, (2007).

4. Canadian Council of Ministers of the Environment (CCME) (2007) Canadian water quality guidelines for the protection of aquatic life: Summary table. (Update 7.1, December, 2007).

5. Cardoso, I., Granadeiro, J.P. and Cabral, H. Benthic prey quality in the main mudflat feeding areas of Tagus Estuary: Implications for bird and fish populations. Ciencias Marinas, aòo/, 34, (003):283-296, (2008).

6. Davis, J.C. Waterborne dissolved oxygen requirements and criteria with particular emphasis on the Canadian environment. National Research Council of Canada, Associate Committee on Scientific Criteria for Environmental Quality, Report No. 13,
NRCC 14100 (1975).

7. Finlayson C.M., Gordon, C., NtiamoaBaidu, Y., Tumbulto, J. and Storrs, M. The hydrobiology of Keta and Songor lagoons: Implications for coastal wetland management in Ghana. Supervising Scientist Report 152. Supervising Scientist, Darwin, Australia, (2000).

8. King, R.P. and Udoidoing, O.M. Perspectives in the development and conservation of freshwater fisheries resources of the Cross River, Nigeria.Transitional Nigerian Society of Biological Conservation, 2, 7-16 (1991).

9. Lawson R.M. The economic organization of Egeriafishing industry on the Volta River. Proceedings of Malacological Society of London. 35: 273-287, (1963).

10. Peltola, P. and Astrom, M. Concentration and leachability of chemical elements in estuarine sulphur-rich sediments, W. Finland. The Sci. of Total Environ., 284: 109122, (2002).

11. Phillips, D.J.H and Yim, W.W-S. A comparative evaluation of oysters, mussels and sediments as indicators of trace metals in Hong Kong waters. Marine Ecology Progress Series , 6: 285-293 (1981).

12. Pople, W. and M. Rogoyska, The effect of the Volta River hydroelectric project on the salinity of the Lower Volta River. Ghana J.Sci., 9(1):9-20, (1969).

13. Prein, M. and Ofori, J.K, Past initiatives for promoting aquaculture in Ghana, p. 1-3. In M. Prein, J.K. Ofori and C. Lightfoot (eds.) 
Research for the future development of aquacuiture in Ghana. ICLARM Conf. Proc. 42, $94 \mathrm{p}$ (1996).

14. Purchon, R.D. A note on the biology of E. radiata Lam (Bivalvia, Donacidae). Proceedings of the Malacological Society of London 35: 251-271 (1963).
15. United Nations Environment Programme (UNEP) Project Development Facility .Volta River Basin Preliminary Transboundary Diagnostic Analysis-Final Report, (2002).

16. United States Environmental Protection Agency (USEPA) .Sediment Sampling. SOP\#: 2016, (1994). 